\title{
Jaderná energie a environmentální krize
}

\author{
Nuclear power and environmental crisis
}

\section{Tomáš Korda}

\section{Zodpovědnost za minulost}

Filozofické reflexe jaderné energie mají většinou etickou povahu. Známý je totiž fakt, že jaderné elektrárny produkují odpad, který zůstane radioaktivní zhruba dalších deset tisíc let. Naše nynější jednání pak působí na budoucnost, která dalekosáhle překračuje horizont lidského uvažování.

Pokud ale člověk není schopen se „rozvrhnout“ do tak vzdálené budoucnosti a stát se potud nesmrtelným, jak si pak může vzít provoz jaderných elektráren na svědomí a nést za své nynější jednání zodpovědnost?

Fyzici, respektive technici a inženýři však před desítkami let snížili palčivost této etické otázky. Řadu let již ve světě stojí a fungují rychlé reaktory, které radioaktivní odpad dokáží znovu spálit, a snížit tak dobu jeho radioaktivity. Nastupující čtvrtá generace jaderných reaktorů dokonce přislibuje natolik účinné spalovaní, že již po tři sta (nikoli tisících) letech poklesne radioaktivita odpadu natolik, že nevybočuje z normy běžného radioaktivního pozadí, ve kterém člověk žije.

Tato skutečnost sice výrazně tlumí často poněkud hysterické reakce vůči jádru, principiálně však neřeší etický problém, za jak vzdálenou budoucnost lze ještě převzít zodpovědnost. Nebot nakonec i těch tři sta let může představovat př́liš vzdálenou budoucnost. Čili ani pak si provoz jaderných elektráren nelze vzít na svědomí.

Podívejme se ale na věc z druhé stránky. Představme si společnost, která by povolovala pouze činy s krátkodobým účinkem, a to s odůvodněním, že jen ty se vlezou do „normy“ zodpovědných činů. Jaké činy by to asi byly? A nesoustředí se současná společnost právě na takovéto činy, jejichž plody si sama ještě stihne užít? Respektive není kapitál tímto společenským myšlením 
tlačen k investicím s krátkodobou návratností? A není slabý stát rovněž funkcí tohoto myšlení, nakolik není schopen dlouhodobějších a strategičtějších investic a trhu tak poskytnout pocit jistoty a dlouhodobé stability?

Jinými slovy není doba, po kterou naše činy působí, mírou toho, za jak vzdálenou budoucnost jsme ještě schopni převzít zodpovědnost? Jak daleko jsme ochotni napnout přítomnost a učinit ji trvanlivější? Čím trvanlivější je naše jednání, čím déle působí, tím je zodpovědnější. Ostatně nejsou činy s krátkodobou působností dětinské, že i malé dítě za ně dokáže převzít zodpovědnost?

Proto bych řekl, že to, co se dané společenství rozhodne pokládat za zodpovědné a co nikoli, je jen a jen na něm a vypovídá to o tom, jak je sebevědomé. $\mathrm{O}$ tom, jak daleko je ochotno se - a svou př́ítomnost - vyšvihnout do budoucnosti.

Naopak „neroztahovat“ se do budoucnosti můžeme pokládat za př́iznak absence sebevědomí. Za známku nezodpovědného podlehnutí činům s krátkodobou účinností, které jsou takové povahy, že na ně lze těžko navázat, produktivně je rozvíjet a natahovat je do budoucnosti, a tím překonávat jejich krátkodobost. Ano, jde o argumentaci kruhem: na krátkodobé činy nelze navázat, a protože na ně nelze navázat, jsou krátkodobé.

Krátkodobost nezodpovědných činů krásně vystihuje př́ísloví, lež má krátké nohy. Jiným dobrým př́kladem je násilí, které se samo ruší a zkracuje si životnost tím, nakolik jen provokuje jemu protichůdné násilí a nikam nevede. Takové činy se samozřejmě dějí a dít budou, to však ale nic nemění na tom, že jsou dětinské a nezodpovědné.

Zodpovědné jednání proto není jednoduše to, které bude působit dlouhodobě, ale spíše to, které působí dlouhodobě, protože na něho lze navazovat a vytahovat ho dál do budoucnosti. Výlučně v tomto smyslu prodlužování životnosti již vykonaných činů bych chtěl rozumět tomu, když se řekne převzít za něco (již uskutečněného) zodpovědnost.

Jak si v tomto kontextu stojí produkce radioaktivního odpadu? Jde skutečně o nezodpovědný čin, který nelze rozvinout? Než odpovíme, že na něj navázat lze, položme si otázku, o čem to svědčí, když společenství považuje produkci jaderného odpadu za nezodpovědnou. Znamená to snad, že si prošlo katarzí, stalo se pokorným a vznešeně se začalo ptát, co bude, až my tu nebudeme a po nás tu zůstane radioaktivní odpad?

Toto tázání se ale jen tváří zodpovědně, nebot kamufluje ten jediný skutečně zodpovědný čin, kterým by bylo přijmout zodpovědnost za radioaktivní odpad. 
K takovému přijetí zodpovědnosti či zavázání se vybízí nejen produkce radioaktivního odpadu, ale v principu každý vykonaný čin. Po svém uskutečnění, co se čin rozebíhá od svého autora do světa, si jako sirotek hledá toho, kdo se ho ujme, kdo si ho přisvojí a dále na něj naváže. Čin jako vykonaná minulost dohání přítomnost. Odjakživa jsme žili v „rizikové společnosti“ a klín vyráželi klínem. Člověk vždy čelil riziku, že ho znenadání přepadne důsledek starých činů (at̉ jeho vlastních, anebo předchozích generací), na které by rád zapomněl, ale nebylo mu to dopřáno.

Řešením není nejednat či se zřeknout minulosti, nýbrž naučit se minulých činů, respektive jejich důsledků konstruktivně zhostit. Nic jiného totiž nezbývá, protože činy se už staly a nemohou se odestát, zvlášt pokud mají celospolečenský význam a představují celé dějinné periody, jako například čtyřicet let komunismu. Ostatně paralela mezi zavržením komunismu a zakopáním radioaktivního odpadu na věčnost pod zem se docela nabízí.

Právě pro svůj celosvětový význam vybízí jádro k tomu, abychom jeho historii nezavrhovali, a naopak se jí konstruktivně zhostili. Na začátku stála atomová bomba, která ukončila a urychlila konec druhé světové války. Japonsku byl ale adresován jen bezprostredni (tj. zničující) význam atomové bomby. Další význam jejího svržení byl zprostředkovaný s účinkem jednak na mezinárodní a jednak na domácí politiku. Mezinárodně byla vědomě či nevědomě adresována Sovětskému svazu. Bezprostředně tedy jádro ukončilo druhou světovou válku a zároveň zprostředkovaně započalo válku studenou a s ní spojené závody ve zbrojení, jež vyprodukovaly ohromné množství jaderných hlavic. Na domácí či civilní politiku jádro zase působilo ve formě výstavby jaderných elektráren produkujících jaderný odpad.

Vyjma komunistického dědictví zanechala tedy po sobě studená válka jaderné hlavice a radioaktivní odpad. Oba činy jsou takové povahy, že se jich lze jen těžko zbavit, nelze je vytěsnit a poslat je někam na skládku do třetího světa jako třeba elektroodpad. Nerudovo „kam s ním“ je v př́ípadě jaderných hlavic a radioaktivního odpadu obzvláště přiléhavé. Obojí lze spolu s Freudem vystihnout německým výrazem „unheimlich“, který je překládán jako cosi tísnivého - co nelze vytěsnit, co je zkrátka tu ve smrtelné blízkosti, co nechce pryč, a co právě proto člověka tísní.

To tísnivé nutí k zodpovědnosti - vzdělává ve smyslu těžko přeložitelného německého Bildung právě proto, že to nelze odkopnout. Proto nezbývá než se s tísnivým naučit žít. Bildung člověka utváří, formuje, kultivuje a učí ho žít s tím, co je. Bildung mění lidskou přirozenost, či přesněji je lidskou přirozeností. 
Následuje tedy otázka, jak se k tísnivým jaderným hlavicím a radioaktivnímu odpadu postavit tak, abychom se nechali tímto dědictvím studené války vzdělat a utvářet. Pochybuji, že bychom tak učinili, pokud bychom toto vyčnívající dědictví minulosti zahrabali pod zem. Aby minulost vypadala, že se nestala. Jaký by byl pak rozdíl mezi zakopáním (uložením) jaderného odpadu pod zem nebo jeho vyhozením doprostřed oceánu, či rovnou do vesmíru, jestliže bychom se na tyto tři činy dívali z hlediska německého Bildung? Obávám se, že žádný.

Ani jeden čin by nám nebyl svědkem, že jsme se vzdělali. Pokaždé by šlo jen o neproduktivní zavrženi (Verwerfung) minulosti, o neochotu se k minulosti přiznat. A to lze pokládat za výraz nezodpovědnosti. Nebot̉ zodpovědnost za budoucnost nese přítomnost jen zprostředkovaně, zatímco bezprostředně ji nese za minulost, protože jen minulé činy jsou něčím skutečným tady a ted'. A pouze na to skutečné lze navázat. Když přítomnost naváže na minulost a převezme za ni zodpovědnost, pozná se to podle toho, že se budoucnosti přestane bát, nebot’ se do ní začne rozpínat, čímž za ni zprostředkovaně přebírá zodpovědnost. $\mathrm{V}$ tomto smyslu je tedy strach $\mathrm{z}$ budoucnosti př́iznakem nezodpovědnosti za minulost.

Na místo nezodpovědného a nesmyslného zakopávání drahocenného paliva pod zem pokládám rozvoj jaderné energetiky za zodpovědný a konstruktivní př́stup k naší minulosti. Navíc sériová produkce nových reaktorů spalujících toto neblahé dědictví studené války přímo ukázkově přebírá zodpovědnost za budoucnost tím, že v podstatné míře řeší současnou ekologickou krizi.

Environmentalisté záslužně upozorňují na „nevyřešený problém“ s jaderným odpadem, na toto tísnivé dědictví a potažmo na neetičnost dalšího provozu jaderných elektráren. Leč tuto svou myšlenku na radioaktivní odpad zpravidla nedotahují do konce - k jejímu dialektickému převrácení. „Vystrašenost“ z radioaktivity jaderného odpadu jim obvykle brání pochopit, že skutečným řešením „nevyřešeného problému“ s jaderným odpadem je právě razantní rozvoj jaderné energetiky. Jen její rozvoj totiž může zajistit spálení radioaktivního odpadu, přesně podle principů cirkulární ekonomiky. Jen na půdě jaderné energetiky lze řešit problém, jejž ona sama vytvořila, po vzoru Parsifalova kopí, které jako jediné léčí ránu, již samo uštědřilo. Jinými slovy psychická obsese radioaktivním odpadem - jestliže je překonaná a jako nit protažená uchem jehly dialektického zvratu - se zasazuje o rozvoj jaderné energetiky. 


\section{Svět není příroda}

Kromě radioaktivního odpadu, jehož pravdou je, že je palivem, se v souvislosti s jadernou energetikou upozorňuje na její pochybnou bezpečnost a často se rovnou přistoupí k otázce: A co Černobyl?

Taková otázka nenápadně podsouvá představu, že černobylská katastrofa vyjevila věčnou esenci dřímající v každé jaderné elektrárně. Žádná elektrárna se tak co do své podstaty neliší od té černobylské. Každou totiž obsluhuje v podstatě tentýž personál: chybující člověk.

Ze strany fyziků a jaderných inženýrů však bylo uvedeno mnoho argumentů proti takovéto esencializaci jaderné energetiky, respektive proti chybné generalizaci vyvozené z jednoho př́ípadu, jehož unikátnost navíc jiné nehody jaderných elektráren jen potvrzují.

Na význam černobylské havárie pro dnešek se tedy pokusíme ukázat jiným způsobem než oslími můstky, jež vycházejí ze zmíněné esencializace a zůstávají stát u prázdné a nicneříkající abstrakce, že všechno je možné, a tudíž to, co se stalo před více než třiceti lety, se může stát i dnes.

Na místo roubování abstrakcí na skutečnost a vytváření umělých přesahů do současnosti bude lepší se podívat, jak se minulost černobylské tragédie sama „vyklání“ do současnosti. Mám na mysli bující faunu i flóru v černobylské zóně. Podobně se již příroda začíná obnovovat i v okolí Fukušimy. Tyto oblasti lehce snesou srovnání se zónou v Tarkovského filmu Stalker.

Zarůstající panelové domy v Černobylu, opice zabydlující se v opuštěných domech ve Fukušimě, to vše probouzí v člověku zvláštní pocit ztráty. Pocit, že příroda polyká lidský svět, je tísnivý, protože se člověku kolem něho zmenšuje prostor, který si na přírodě vydobyl a kterému se právem říká svět, nakolik se dere na světlo z přírodní tmy.

Požírání světa přírodou vzbuzuje pocit úzkosti, který lze jen těžko zaměňovat s pocitem rozhořčení vyvolaným opačným procesem, kdy člověk ničí prrírodu, aby ji přetvořil ku obrazu svému. Když totiž v černobylské zóně zaniká svět lidské civilizace, vniveč jde celá práce investovaná k vytvoření této umělé, druhé skutečnosti. Práce pojí člověka se světem. Práce tvoří a přetváří svět. Práce odděluje svět (člověka) od přírody. A proto když v Černobylu příroda před našimi zraky „požírá“ svět, člověk cítí, že ztrácí i kus sebe sama, že přrichází o kus světa, část svého prodlouženého umělého těla.

Domnívám se, že ničení přírody člověkem tento pocit úzkosti nenavozuje. Příroda není svět. Když hoří prales, není to stejný pocit, jako když př́roda pojídá černobylské panelové domy. $\mathrm{V}$ prrípadě zničené přírody nelze mít 
pocit, že přicházíme o něco, co je naší součástí, že je nám bezmála amputován kus našeho těla. Příroda není naším prodlouženým tělem. Její ničení necítíme.

Ve své knize Being Ecological environmentální myslitel Timothy Morton doufá a předpokládá, že u člověka (čtenáře) navodí právě tento pocit ztráty kusu sebe sama. Například když přirovná současné masové vymírání druhů k říznutí se tak ostrým skalpelem, že toto krvácení člověk ani necítí.

A přesně v tom je problém. Člověk neciti masové vymírání druhů. Necítí přírodu, protože když už ji fyzicky skutečně cítí, jako například hořící les, nevede ho to k přemítání a pocitování ztráty, ale k potřebě utéct a zachránit se. Člověk necítí prrírodu, jelikož v ní již nežije a není její součástí jako zvíře. Člověk žije ve světě. Ba co víc. Člověk si pracně vybudoval tuto umělou skutečnost jménem svět právě za účelem toho, aby přírodu necítil, aby se nemusel zajímat o to, co se v ní děje. Př́roda je totiž jednak nebezpečná a jednak nudná, nebot̉ se v ní věčně opakuje totéž.

Ve své podstatě je člověk zvíře př́írodě nepřizpơsobivé, které celé své dějiny intenzivně pracovalo na tom, aby se přírodě přizpůsobovat nemuselo. Klimatická krize proto neznamená a nemůže znamenat nic jiného, než že př́roda na člověka opět doléhá a nutí ho se jí přizpơsobit. Čemuž se však člověk z důvodu své výše zmíněné podstaty vzpírá. Nechce př́írodu pocitovat. Dokonce představa, že by se přírodě musel přizpơsobovat a například snižovat své civilizační standardy, člověka přímo uráží. Nebot člověk je přece svobodný a raději zemře jako člověk ve světě, než aby se přírodě přizpůsobil, jako to dělá zvěř.

Člověk proto klimatickou krizi nejprve ignoruje, bagatelizuje, zesměšňuje a nakonec odmítá. Řekne si, že změny klimatu probíhaly odjakživa a dnes se nic nového neděje. Když např́ílad udeří hurikán nebo požáry v důsledku sucha, vždy si může říci, že nejde o změny klimatu, ale pouze o špatné počasí, to jest cosi nahodilého, a nikoli nutného.

Tato neochota se přizpůsobit a ignorovat skutečnost se však postupně stahuje na rovinu prázdných řečí, kterým neodpovídají žádné činy, nebot člověk se stále častěji musí evakuovat v důsledku přírodních katastrof, anebo na ně v daleko větší míře umírá. Člověk si tedy pouze nalhává, že se př́írodě nepřizpůsobuje, přitom ale dělá opak. Vzniká tak rozpor mezi podstatou člověka coby zviŕretem, jež je přírodě nepřizpo̊sobivé, a skutečnými činy, jimiž se z důvodu klimatických změn člověk přírodě přizpơsobuje. Tento rozpor musí vyřešit. Klimatická krize tedy člověka nutí najít způsoby, aby se prŕírodě nemusel přizpůsobovat, aby zase odpovídal svému pojmu zviŕrete od př́rody osvobozeného. 
Nakolik černobylská zóna vyvolává pocit úzkosti ze ztraceného světa, natolik nutí mezi ním a přírodou rozlišovat. Toto rozlišení nemá jen ontologický, nýbrž i etický význam. Svět by se měl nad př́rodu pozvedat a nikoli se do ní vstřebávat. Toto rozlišení je však nesamozřejmé. Hegel například ostře kritizuje Spinozu za to, že mu chybí pojem světa, který následkem toho spadá do jednoho celku s prŕrodou. Tuto výtku Hegel formuluje z pozice své filozofie ducha, nebot duch se nevznáší ani v kosmu (jak naznačuje Charles Taylor) a není ani zabředlý v přírodě, nýbrž se uskutečňuje ve světě. Domnívám se, že když u Spinozy chybí světu vlastní skutečnost vymaněná z prŕírody, neměl by u něho mizející svět v černobylské zóně vyvolávat žádný afekt ztráty sebe sama. Vyjdeme-li totiž ze Spinozy, svět si na př́rodě nikdy nevydobyl svou vlastní nezávislou skutečnost. Svět lidské civilizace přirozeně odchází, tak jako přichází.

Udělit světu lidské civilizace vlastní na prrírodě nezávislou a přírodě odcizenou skutečnost považuji za prvořadý úkol dneška, jsme-li svědky environmentální krize. Rozlišení přírody a světa totiž umožňuje vidět současnou environmentální krizi ve staronové perspektivě. At̉ už jde dnes o osvojení si jádra či jako kdysi o osvojení si ohně, o umění slévat kovy či o průmyslovou revoluci, pokaždé se jedná o civilizační skok vpřed, kterým se svět (lidské civilizace) povytahuje ze své zabředlosti v př́rodě, jež ho doposud ohrožovala. Jen nakolik svět nechává přrírodu vzad, jde vpřed. Když ke stejnému ohrožení přírodou dochází i dnes v době klimatických změn, je potřeba se od př́rody znovu odrazit.

Filozofické rozlišení světa a přírody dovoluje a vlastně i přímo vybízí k hledání způsobů, jak opětovně osvobodit svět od utiskující prrírody, jak ho znovu vytáhnout z přírody ven na světlo, tentokrát v planetárním měřítku.

Množství energie uvolněné z jádra atomu při jeho štěpení samo odpovídá na otázku, co je materiálně či energeticky schopné pozvednout celý svět lidské civilizace nad přírodní hladinu a dovolit tak světu romanticky shlédnout na př́irodu, jako slavný Poutnik nad mořem mlhy z obrazu Caspara Fridricha Davida.

Množství energie uvolněné z jádra atomu je sice tím, bez čeho by dějiny emancipace světa od přírody nemohly pokračovat, není to však ten poslední argument pro rehabilitaci jaderné energetiky. Neméně podstatný je také fakt, odkud uvolněná energie vyvěrá. Kypí totiž z jádra atomu, které symbolicky i skutečně představuje základní stavební kámen přírody. S roztržením atomu tak padla poslední bašta přírody.

Svět lidské civilizace tedy emancipuje atomová energie rovněž tím, že pramení z rozlomené př́rody. Brání tak její absolutizaci a fetišizaci. Pozvednutí 
přírody na náhražku boha je nesmírně nebezpečné, je-li právě nyní nejvyšší potřebou doby se od přírody osvobodit a znovu tak ustát smrt boha, tentokrát zakukleného v př́rodě. Snad již brzy bude svět vzpomínat na přírodu v dobrém, jak ho svou ekologickou krizí přinutila se od ní osvobodit.

\section{Mgr. Tomáš Korda}

Doktorand FF UK, Ústav politologie, Filozofická fakulta, Univerzita Karlova

U Křriže 8, 15800 Praha 5 - Jinonice, Česká republika

t.korda@seznam.cz

$+420728455339$

Toto dílo Ize užít v souladu s licenčními podmínkami Creative Commons BY-NC-ND 4.0 International (https://creativecommons.org/licenses/by-nc-nd/4.0/legalcode). Uvedené se nevztahuje na díla či prvky (např. obrazovou či fotografickou dokumentaci), které jsou v díle užity na základě smluvní licence nebo výjimky či omezení přislušných práv. 